\title{
A MODERNIDADE DOS CONTRATOS AGRÁRIOS
}

\author{
Fábio Maria De-Mattia \\ Professor Titular do Departamento de Direito \\ Civil da Faculdade de Direito da Ĺniversidade de \\ São Paulo.
}

\begin{abstract}
Resumo:
Os contratos agrários são instrumentos jurídicos a serviço do cumprimento da função social da propriedade. as noções de função social da propriedade rural e função social dos contratos agrários se completam. Essas e outras assertivas dos contratos agrários são abordadas pelo autor combinando-as com as de autores nacionais e internacionais, mediante conclusões de um anexo contendo anotações sobre a especialidade do Direito Agrário.
\end{abstract}

Abstract:

The agrarian contracts are legal instruments in the service of the fulfillment of the social function of the property, the slight knowledge of social function of the country property and social function of agrarian contracts complete themselves. These and other assertives are boarded by the author combining them with the ones of national and international authors, by means of conclusions of an annex containing notations on the specialty of the Agrarian Law.

Unitermos: Contratos agrários; autores nacionais e internacionais.

Keywords: Agrarian contracts; national and international authors.

1. Aspectos gerais.

Fernando $\mathrm{P}$. Brebbia ressalta que o tema da contratação agrária é suficientemente amplo, além de impreciso, daí caber a indagação se existe a rigor uma categoria especial de contratos agrários, distinta e diferenciada dos contratos de direito civil e comercial no âmbito do direito privado, e do direito administrativo no direito público. Acrescenta que, se esta categoria jurídica existir, dever-se-ia estudar após a especialidade dos contratos agrários e do problema se tais contratos podem se reconduzir a um único tipo. como parece se aceitar geralmente em doutrina. ${ }^{1}$

1. BREBBlA, Fernando P Contratos agrários. 2. ed. atual. e ampl. Buenos Aires: Editorial Astrea. 1992, p. 2. 
O primeiro aspecto indicado não é senão; sob um certo modo, mais uma conseqüência daquela questão mais geral que é a especialidade do direito agrário e sua ubicação em relação ao direito comum. ${ }^{2}$

Em conseqüência, uma corrente doutrinária sustenta a existência dos contratos agrários como categoria contratual diferenciada - especialmente dos contratos do direito civil, caracterizada como formas de realização da empresa agrária em terreno alheio, relação jurídica encaminhada ao aproveitamento racional do solo e de bens suscetíveis de frutificação - mediante a vinculação harmônica entre o capital e o trabalho e sem que este segundo fator convirta a quem o aporte em proletário, subordinado jurídico, econômico e tecnicamente à terra. ${ }^{3}$

A especialidade dos contratos agrários se consubstancia porque neles um verdadeiro empresário conduz a exploração e assume seus riscos ou os divide com o proprietário do fundo que concede seu uso. Estes contratos têm por objeto a utilização pelo não titular de um direito real sobre fundo rústico e das coisas destinadas a obter um maior rendimento desse fundo, ou de retirar dele alguma utilidade, como dizem alguns autores. ${ }^{4}$

Os atos relacionados com a produção agrária eram considerados civis e por conseqüência eram tais todos os contratos dirigidos a constituir e a organizar a empresa ou estabelecimento agrário. ${ }^{5}$

Enrico Bassanelli, ao examinar a natureza jurídica da figura do agricultor, ensina: "o agricultor não é um intermediário no intercâmbio dos bens, é um produtor que coloca em circulação o bem novo obtido da terra, ou seja, o produto agrícola ou fruto natural. Também na definição legal de alguns dos mais importantes tipos de contrato agrário, como a parceria e a colônia, evidencia-se o resultado da produção sobre a forma dos produtos (e utensílios) para repartir. ${ }^{6}$

Antonio Carrozza, ao abordar a relação entre contrato agrário e empresa agrária, observou que a relação entre os dois termos, na doutrina italiana, de fato se resolveu um no outro. Apontou que para demonstrar a existência da categoria contrato

2. Id. Ibid. op. cit. p. 2.

3. Id. Ithid. op. cil. p. 3-4.

4. Id. Ibid. op. cil. p. 4.

5. MASSART. Alfrudo, op. cit. p. 16-17.

6. Id. Ibid. op. cit. p. 20 e nota 29. 
agrário dever-se-ia partir da empresa em todas as suas fases (desde a constituição até sua extinção). Para alcançar o contrato agrário, o importante é buscar o laço de união entre empresa constituida e o contrato que a constitui. ${ }^{7}$

Alfredo Massart aponta que o estudo do tema contrato agrário, como de outros fundamentais para os agraristas, deve abranger o empenho e a responsabilidade de todos os cultores do Direito Agrário porque, sob um ponto de vista, os argumentos de fundo guardam relação com todos os ordenamentos jurídicos de qualquer latitude, porque subsistem manifestas as tendências do direito agrário (fala-se da parte geral) a apresentar um núcleo de princípios e de instituições vảlidas universalmente. ${ }^{8}$

Alfredo Massart observa quanto demorou uma delineação teórica no seu conjunto, em suma, carecendo uma construção dogmática geral e uma classificação cientificamente apreciável. ${ }^{9}$ O elemento faltante que parece não ter estado presente é o elemento organização econômica. ${ }^{10}$

Na definição de direito agrário deve estar presente a noção do momento empresarial, a referência à empresa agrária, a preordenação do contrato à empresa, pois para Enrico Bassanelli o contrato nasce antes do que a empresa, em momento anterior ao início da atividade econômica, a empresa não nasce simultaneamente à estipulação do contrato. A "preordenação" do contrato à empresa significa na lição de Bassanelli que os contratos agrários têm função instrumental com respeito a empresa agrária." Existem os contratos agrários de constituição de empresa e os contratos agrários de empresa propriamente ditos.

Mas, segundo Alfredo Massart, os partidários deste ponto de vista limitaram-se a mencionar uma teoria geral do contrato agrário mais do que desenvolvê-la completamente, dai o maior êxito obtido em tentativas mais recentes de especialistas como Natalino Irti, Giovanni Galloni e Antonio Carrozza que abandonaram esta tese para construir a teoria do contrato agrário exclusivamente com

7. MASSART. Alfredo. Naturaleza juridica del contrato agrário: problemas dogmáticos... em Síntase de derecho Agrário, ob. cit. p. 104.

8. Id. Ibid. op. cil. p. 104.

9. Id. Ibid. op. cit. p. 106.

10. Id. Ihid. op. cit. p. 106-107.

II. Id. Ihid. op. cit. p. 107. 
referência à empresa. ${ }^{12}$

Alfredo Massart esclarece que também Antonio Carrozza parece participar desta tese, observando que "uma tal concepção supcrou e reassumiu por sua maior organicidade as preexistuntus posições doutrinárias" Deve se acentuar que a tuse de Giovanni Galloni ć, substancialmente, acolhida também por Antonio Carrozza em seu enunciado de fundo, ainda que não participc de aspectos particulares da mesma, como por exemplo, os elementos que seriam idôneos para caracterizar a estrutura de todos os contratos agrários. Aspectos estes marginais com respeito ao ponto central, enquanto a causa do contrato agrário é a constituição da empresa. ${ }^{13}$

Alfredo Massart explica que se tem observado que uma vez constituída a empresa agrária, todos os contratos estipulados pelo empresário para o exercício da organização da mesma são igualmente considerados como contratos "agrários" Daí a dupla classificação dos contratos agrários em sentido estrito e dos contratos agrários da empresa, que seriam precisamente aqueles consubstanciados na atividade de gestão. $^{14}$

Pondera que esta nova concepção e classificação dos contratos agrários, sob um aspecto, se aparta definitivamente das teses tradicionais, quer abrangem na relação jurídica a terra e o trabalho, quer predomine a natureza do objeto concebido em sentido lato ou a natureza dos fatos e das causas qualificantes da produção agrária; enquanto que, sob outro aspecto, impõe-se à alenção dos jusagraristas como argumento novo de estimulantes reflexões e de estudo. ${ }^{15}$

Entre os que participam e aceitam este novo modo de considerar o contrato agrário, como seria de supor, não faltam tomadas de posição e puntualização pessoais. A titulo de exemplo, Alfredo Massart cita a crítica, para ele justa, que Antonio Carrozza dirige contra os que (como Giovanni Galloni), ao menos num primeiro momento, sustentaram a automaticidade do nascimento da empresa no próprio momento em que se aperfeiçoava o contrato. ${ }^{16}$

12. Id. Ibid. op. cit. p. 108.

13. Id. Ibid. up. cit. p. 108.

14. Id. Ibid. op. cit. p. 108.

15. Id. Ibid. op. cit. p. 109.

16. Id. Ibid op. cit. p. 109. 
Por sua vez, Antonio Carrozza, apesar de não duvidar do caráter genérico da relação entre contrato e empresa agrária, determina com precisão: contrato imediato e automaticamente constitutivo da empresa ou melhor, contrato que disciplina a constituição de uma empresa (eventual e futura). Sua inclinação pela segunda solução estava implícita na interrogação, segundo a reflexão de Alfredo Massart. $^{17}$

Antonio Carrozza, coadjuvando os criadores da tese em exame, tese que entra em crise sobretudo na presença de contratos atípicos agrários, após ter novamente ressaltado "que é verdadeiramente indispensável que o contrato se preste a ser utilizado para dar vida a uma empresa agrária (ou para gerí-la)", enuncia um critério muito original: "Para ver si un contrato (nuevo o de dudosa naturaleza) puede ser considerado como agrario o no, ésto há de verse solo a posteriori, ésto es, cuando el concesionario (de fundo rústico, pero tambiém de ganado, etc.) se haga empresário" 18

Alfredo Massart explica: considerando que a qualificação do contrato agrário produz certas conseqüências de dircito positivo, ustas conseqüências produzirse-ão somente se em concreto nasce a empresa porque, caso contrário, permanece fora do campo de direito agrário. ${ }^{19}$

Portanto, seguindo o critério de empresa agrária como qualificante, excluídos os casos mais conhecidos e tradicionais (parccria, arrendamento, parceria em gado) nos quais o nascimento da empresa é de se esperar, geralmente a qualificação do contrato agrário se dá por admitida por uma longa tradição desde o momento da estipulação com todas as conseqüências; já em todas as outras hipóteses, principalmente se são atípicas, o "concedente" (usa-se aqui a expressão em sentido genérico) não pode saber com certeza que destino se seguirá a um contrato de que se é parte, de Direito Civil por excmplo, encontrando-se não ad-libitum do concessionário. Certamente através de seu comportamento. considera-se como parte de um contrato agrário. O concedente sofreria deste modo as consequêencias de um direitu potestativo anômalo do concessionário. ${ }^{20}$

17. Id. Ibid. op. cit. p. 109.

18. Id. Ihid op. cit. p. 110.

19. Id. Ibid. op. cit. p. II0.

20. Id. Ihid. up. cil. p. 110. 
Alfredo Massart aponta que existe um tanto de perplexidade a respeito do mérito do critério de semelhante relação genética da empresa para o contrato agrário e, sobretudo, existe perplexidade a respeito da possibilidade de qualificar um contrato como agrário pelo fato que subsista a empresa que o qualifica como tal.

O critério de individuação da natureza de certos contratos só a posteriori, além de ir contra a certeza do direito, parece forçado.

A análise no sentido de se admitir a classificação dos contratos agrários em contratos para a empresa e da empresa ou da organização da empresa já constituída suscita perplexidade.

As vantagens em se admitir a existência da categoria dos contratos "agrários" da empresa seriam exclusivamente teórica, porém não contribuem - sob este ponto de vista para delinear a imagem do direito agrário com devida clareza. ${ }^{21}$

Esta tese deixa porta aberta para a possibilidade de estender, desmedidamente, o número de contratos que poderiam ser considerados como agrários, apesar de muitos deles igualmente terem sido, até hoje, legitimamente reivindicados como objeto do estudo próprio dos cultores de outros ramos do direito. $^{22}$

Alfredo Massart conclui que sequer a interdisciplinariedade dos ramos jurídicos justifica a constituição de uma categoria ou a reivindicação de uma nova categoria de contratos agrários com fundamento em um nexo genérico e, freqüentemente, não melhor individualizado, com a empresa agrária. ${ }^{23}$

Antonio Carrozza se posiciona favoravelmente ao considerar os contratos de empresa como contratos agrários, mas ressalva ser questão controvertida sabcr quais e quantos são tais contratos. Esclarece que a doutrina italiana se apresenta dividida: alguns autores admitem integrando a categoria de contratos de empresa, os contratos de trabalho subordinado na agricultura e os contratos de crédito agrário (Giovanni Galloni), com os quais o agricultor pretende a disponibilidade do fator de produção "trabalho" e do fator "capital" (de exercício); outros autores se manifestam dispostos a incluir no grupo em exame somente alguns particulares contratos de trabalho (aqueles que têm caráter de gestão e os de retribuição pela parceria), como

21. Id. Ibid. op. cit. p. 111.

22. Id. Ibid. op. cit. p. 111 .

23. Id. Ibid. op. cil. p. III. 
para Natalino Irti e Giovanni Galloni. e excluindo os contratos de crédito agrário, como parece fazê-lo Natalino Irti. ${ }^{24}$

Antonio Carrozza se posiciona favoravelmente ao inscrir entre os contratos agrários de empresa todos os contratos de trabalho aplicáveis à agricultura, com a finalidade expressa de se evitar que os contratos de trabalho referidos sejam assumidos sem deixar vestígio no Direito do Trabalho. Antonio Carrozza inclui todas as operações de crédito agrário como contratos de empresa. ${ }^{25}$

Alfredo Massart considera mais convincente, pelo menos no estágio atual da doutrina. o argumento sobre a agrariedade das operações de crédito agrário (de exercício) e invoca como motivo de sua posição a vinculação evidente entre o financiamento e a própria empresa. O contrato de crédito agrário ajusta-se, na lição de Fragali, a um "mútuo de finalidade (qualificada)", o que ressalta sua peculiaridade distinguindo o crédito agrário do contrato de mútuo. Alfredo Massart conclui que esta peculiaridade vai se acentuando. ${ }^{26}$

O tema da qualificação de uma categoria de contratos como "agrários" tem especial relevância para os agraristas, daí ter Alfredo Massart após acurado estudo dos mesmos, concebido seu entendimento. Desde logo afasta a importância da relação entre contrato e empresa quando se pretende investigar o fundamento da agrariedade de um certo número de contratos e conclui que para a individuação da essência do contrato agrário a vinculação entre contrato e empresa, ou vice-versa, sob vários aspectos não parece utilizável, embora seja assunto de interesse sob o aspecto juridico. $^{27}$

Alfredo Massart explica que se a empresa, como se di\% usualmente, "entra" direta ou indiretamente no contrato agrário e. portanto, se faça de algum modo presente na dinâmica contratual, não parece que a causa do contrato agrário se identifique com a finalidade de constituição da empresa no pólo de uma das partes, nem que o contrato agrário seja considerado o instrumento jurídico com o qual conta o titular de direito sobre o fundo (titular dos poderes de destinação do fundo segundo Giovanni Galloni) para exercitar a faculdade de escolher o modo de condução do

24. Id. Ibid. op. cil. p. 112.

25. Id. Ibid. op. cit. p. 112.

26. Id. Ibid. op. cil. p. 112.

27. Id. Ibid. op. cil. p. 114. 
mesmo, nem que quisesse dar vida a uma empresa em favor de terceiros. Por este caminho, Giovanni Galloni chegou a configurar o arrendamento como um contrato pelo qual o arrendador ou arrendante cede os poderes empresariais ao arrendatário. ${ }^{28}$

Ademais, se em alguns casos, por exemplo na parceria ou na coopurativa de produção de fundo rústico (como em outras formas associativas), a constituição da empresa surge em primeiro plano como expressão da vontade das partes contratantes, no mesmo contrato de arrendamento de fundo rústico se tem em mira apenas a empresa, levando-se em conta exclusivamente um dos pólos contratuais: os interesses da parte arrendatária. Despreza-se, totalmente, o outro pólo: 0 arrendador que tem interesse no equivalente, a renda. ${ }^{29}$

Alfredo Massart exemplifica o acima asseverado, se um proprietário, supomos um herdeiro (por exemplo, a viúva, um fillho menor, etc.) é totalmente incompetente em matéria agrária e por tanto incapaz, sob o ponto de vista técnico econômico, pergunta-se: quais poderes empresariais poderá ceder se nunca os possuiu (estipulando um arrendamento) $?^{30}$

Para Alfredo Massart, a constituição de uma empresa agrária não é a causa qualificante do contrato, tanto no caso de o proprietário não querer ou não cultivar por si mesmo poder os próprios fundos, preferindo obter a chamada renda fundiária como na eventualidade de uma sociedade (por exemplo uma imobiliária), isto é, uma sociedade ativíssima de tipo moderno, com a qual e conatural um investimento e um alto risco, a qual adquire terrenos e os administra sob várias formas para obter renda também por breve tempo. Pergunta-se: como se poderia afirmar que com a escolha de arrendamento a sociedade financeira objetiva constituir, principalmente. a empresa de um arrendatário pequeno ou grande? $?^{31}$

O eminente especialista acrescenta ainda outro exemplo: se em uma zona geográfica com área apoucada onde se produz vinho (ou flores, ou essências perfumadas. ou frutos....). um grande empresário ou sociedade multinacional arrendasse áreas, situadas na circunscrição ou no território onde há um consórcio, com o único escopo de evitar que tercciros pudessem cultivar produtos com

28. Id. Ibid. op. cit. p. 114-115.

29. Id. Ibid. op. cit. p. 115.

30. Id. Ibid. op. cil. p. 115.

31. Id. Ibid. op. cit. p. 115-116. 
denominação de origem controlada e garantida, diante de tal situação, como se negaria a natureza jurídica de contrato agrário a tal negócio jurídico e como visualizaria em seu elemento causal o nascimento da empresa do arrendatário? ${ }^{32}$

Situações análogas podem ser encontradas aplicáveis ao contrato de comodato de fundo rústico, outro exemplo de contrato em que inexiste a mínima intenção para ambas as partes de criar a empresa agrária com todas as conseqüências juridicas decorrentes. ${ }^{33}$

Chegados a este ponto, pode-se objetar: então a função e a tutela da empresa não têm relevância? Alfredo Massart responde: o cunceito principal de empresário (sobretudo se é arrendatário) é depreciado justamente no momento em que a legislação de quase todos os países favorece o momento empresarial e de fato no exemplo deixaria de proteger o concessionário em relação ao proprietário (especialmente se absenteísta). A resposta é negativa. É certo que são necessárias normas para tutelar o que representa o momento dinâmico da economia, para tutelar a empresa em todas as suas formas, para tutelar e manter ao arrendatário as vagas para trabalho justo. porém, esta tutela, em agricultura, é a do contratante mais fraco, ou que se pressupõe como tal, tutela inserida ex lege no contrato, integrando eventualmente o objeto do contrato. Neste sentido, todos os contratos, e não-só os agrários, no mundo moderno são concebidos, mais do que nunca, como efetivação de um ajuste "equo" entre as partes; acordo imposto de fora sob o pressuposto de improbabilidade normal de a categoria mais débil obter o resultado econômico do contrato. ${ }^{34}$

Alfredo Massart ensina que a essência, rectius, a "agrariedade" da natureza do contrato agrário não se mudou. A causa do contrato é e permanecerá um ponto inabalável do direito agrário. Melhor ainda hoje, que com os avanços da ciência agronômica se desenvolvem formas novas de cultivo (estufas. aquacultura, etc.) e o fundo vai perdendo cada vez mais a posição central que ocupava no passado e já não é mais o elemento indispensável e de maior valor econômico da exploração. Salientou-se que o núcleo fundamental da atividade agricola sempre se constituiu do ciclo biológico da criação de seres vivos, sejam animais ou vegetais, utilizando as forças da natureza, e seja acrescentado. desde que esteja presente a impresa, como

32. Id. Ihid. op. cit. p. 116.

33. Id. Ibid. op. cit. p. 116.

34. Id. Ihid op. cit. p. 116-117. 
sucede na maior parte dos casos e nas eventualidades em que a atividade agrária não se desenvolva em forma de empresa. ${ }^{35}$

O contrato agrário se serve precisamente da obtenção da utilização das energias naturais, praticar cultura das plantas e a criação de animais. Esta é, parece, a verdadeira causa "genérica" do contrato agrário. Se prontamente nasce a empresa, esta causa genérica estreitamente conexa ao ciclo biológico virá a ser, também, objeto da empresa. ${ }^{36}$

Os contratos agrários podem ser estipulados entre empresários, por exemplo, o intercâmbio de mão de obra entre pequenos empresários ou entre um empresário e um empresário capitalista (exemplo: o arrendamento em que o arrendatário não é cultivador direto). ${ }^{37}$

Alfredo Massart aceita a classificação dos contratos agrários em contratos associativos e contratos de intercâmbio e, com relação à natureza agrícola dos contratos agrários, aprova a categoria dos contratos de concessâo em sentido estrito (cujo objeto é um fundo, um bosque, gado), porém também o capital de instalação: dinheiro, formas diversas de financiamento, etc. e as concessões de desfrute para cultivar novas variedades vegetais, distinguindo-a dos contratos de concessão mista, nos quais uma ou ambas partes prestam também o trabalho (exemplo clássico: a parceria). ${ }^{38}$

2. Análise da limitação da autonomia da vontade na formação dos contratos agrários e as conseqüências quanto à sua tipologia.

A tendência tem sido para uma substituição generalizada da autonomia dos particulares por uma autonomia integrada pela intervenção do legislador, que causa a substituição do privado em relação ao público.

Quanto aos contratos agrários, há um processo de integração recíproca e constante entre o público e o privado, pelo qual os contratos agrários funcionam como instrumentos de publicização e ao mesmo tempo de privatização dos fatores

35. Id. Ibid. op. cit. p. 117.

36. Id. Ibid. op. cit. p. $117-118$.

37. Id. Ibid. op. cit. p. 118

38. Id. Ibid. op. cil. p. 119. 
produtivos e manifestam uma sua especialidade comparada com a figura contratual tradicional. A autonomia contratual, em geral, reflete não apenas os interesses e os escopos das partes, mas também os problemas de ordem sócio-econômico juridicamente relevantes. ${ }^{39}$

O contrato agrário, também enquanto preordenado para administrar ou construir uma organização produtiva agrária, persegue de modo peculiar os interesses e os escopos das partes juntamente com as finalidades econômico-sociais juridicamente relevantes. $^{40}$

O número variado de contratos agrários gerados ou não pelo costume ou pela lei e a margem ampla concedida a autonomia contratual causaram "a expansão dos tipos contratuais, compostos ou híbridos (mistos) ou anômalos" na lição de Enrico Romagnoli, concebidos freqüentemente com o fim de transgredir normas imperativas. ${ }^{41}$

O contrato agrário, mesmo não perdendo sua natureza negocial, revelase um ato em contraste natural com o ato livre ou facultativo dirigido a tutelar o contratante mais fraco e idôneo a prevenir uma disparidade substancial de tratamento entre as partes. Isto gerou um contraste entre os conceitos expressos pelo princípio da igualdade e pelo da paridade de tratamento no interior das relações jurídicas e assim chegou-se a denunciar ulteriormente a "crise da liberdade contratual" ${ }^{42}$

Fernando Salaris cita Antonio Carrozza, que estuda a necessidade de realizar no âmbito das relações agrárias "a igualdade substancial" entre sujeitos de interesses contrapostos. ${ }^{43}$

Fernando Salaris ensina que no âmbito das relações agrárias é necessário realizar não tanto o equilibrio genérico entre parte ou contraparte quanto proceder a uma utilização melhor da empresa para obter um rendimento maior $e$ racional dos bens utilizados, numa medida proporcional às exigências sociais do trabalho, seja individual seja organizado. Trata-se de uma aplicação flexível dos

39. SALARIS, Fernando, op. cit. p. 21.

40. Id. Ibid. op. cit. p. 21-22.

41. Id. Ibid. op. cit. p. 22-23.

42. Id. Ibid. op. cit. p. 26-27.

43. Id. Ibid. op. cit. p. 27. na nota 32 cita a obra recente do eminente Antonio Carrozza, "Lezioni di diritto agrario, 1. Elementi di teoria generale, Milano, 1988, p. 91. 
princípios de igualdade e de solidariedade. O contrato agrário não é mais o instrumento privilegiado de autonomia das partes. Cita Fmilio Romagnoli sobre a sujeição do contrato agrário ao regime do "contrat dirigé" 44

No âmbito das relações agrárias o Fstado, de modo especial, não se posicionou como contraparte respeitável inclinada a sustentar e reforçar apenas a posição da parte fraca; ele se revela como ente que tutela os interesses sociais no seu conjunto, com o fim de operar em base a um princípio de justiça superior para estabelecer o equilíbrio entre as várias categorias de trabalhadores e tutelar os valores protegidos pela Constituição, entre os quais avulta o trabalho. ${ }^{45}$

Constitui dado incontroverso o predomínio ocorrido sobre a propriedade agrícola, ou seja. o lugar sempre mais importante reconhecido ao trabalho organizado na empresa. $O$ trabalho organizado para fins produtivos constitui a mesma causa do contrato de arrendamento. O empresário, seja arrendatário, cultivador direto, seja concessionário não cultivador direto, mantém obrigações mínimas em relação aos privados e máximas, ao invés, em relação à coletividade. ${ }^{46}$

A ligação entre os institutos contratos agrários e propriedade da terra reside na circunstância de ao se tratar daqueles negócios jurídicos, não estarmos abordando autonomia contratual no sentido que disciplina os poderes dos particulares quanto a determinados tipos de contrato e a seus "objetos", relativos aos "fundos rústicos", mas com tal conteúdo cuida-se da propriedade da terra, por se relacionar com aspectos fundamentais da condição proprietária. ${ }^{47}$

Com efeito, não se deve subestimar que a regulamentação da autonomia contratual nos contratos agrários mantém estreita ligação e forte incidência na situação dos proprietários. ${ }^{48}$

Na lição de Fernando Brebbia, a especialidade nos contratos agrários se revela também pela presença constante de normas com caráter de ordem pública, e isso não ocorre só porque o legislador assim o expressa, mas porque se impõe pela

44. Id. Ibid. op. cit. p. 28-29.

45. Id. Ihid. op. cit. p. 29.

46. Id. Ibid. op. cil. p. 29-30.

47. FERRERO, Enzo, La Legge 203/1982 sui contratti agrari, Torino: G. Giappichelli Fditore, 1983. ค. 5-6.

48. Id. Ibid. op. cil. p. 7. 
sua própria natureza e finalidade. A imperatividade das normas se justifica pela necessidade impostergável de titular a produção que se realiza sob regulação de contratos de empresa, proteger a parte economicamente mais fraca na relação contratual, assegurando-lhe a estabilidade no imóvel e condições de vida e trabalho dignas. Trata-se de ordem pública econômica, que encontra seu fundamento principal na necessidade de tutelar a produção, e apesar deste interesse costumar coincidir com yuem explora a terra, isto não é necessariamente assim, porque a parte denominada "economicamente mais débil" não é aquela que possui menos recursos. senão a que carece de terra para explorar, e inversamente, o concedente, ainda que necessite de recursos ou de patrimônio ou este seja igual ou inferior ao do concessionário. podendo estar assim mesmo em condições de contratar, de impor determinadas condições. $^{49}$

O contrato agrário tem atributos próprios, idôneos a se conceber uma teoria geral em algum modo diferenciada em relação à teoria geral do contrato civil.

As técnicas de conversão do contrato, realizadas através da adesão a esquemas preestabelecidos pelo legislador, diferem profundamente daquelas para a Cormação ordinária do contrato. ${ }^{50}$

O contraste é evidente no modo de formação do contrato, realizada através de esquemas legais, se comparado com a concepção tradicional da autonomia privada e com a liberdade do querer das partes. ${ }^{51}$

O fundamento da eficácia do contrato agrário, formado através da adesão a esquemas normativos - salvo alguma exceção ainda que relevante. o que confirma a regra geral - consiste não em um fato volitivo de ambas as partes, mas em um fato meramente apto a ser conhecido por apenas uma das partes, o concedente.

O acordo em sentido técnico falta. vez que é o legislador, com uma norma expressa, quem predispõe e impõe a própria vontade aos contratantes. ${ }^{52}$

Alfredo Massart, cuidando da empresa zootécnica, acena que a propósito da chamada teoria dos contratos agrários. a doutrina deverá recomeçar desde o início. Os contratos "agro-zootécnicos" não têm aquela carga sociológico .

49. BREBBIA, Fernando P., ob. cit. p. 24 × 25 e nota 36 na p. 27.

50. SALARIS, Fernando. op. cit. p. 75.

51. Id. Ibid. op. cil. p. 75.

52. Id. Ibid. op. cil. p. 75. 
política, aquele "pathos" que por decênios ocasionou lites e rancores entre a propriedade da terra e a empresa.

Lembra o que ocorre na Itália onde vários contratos agrários desapareceram (parceria, colônia, etc.) e há, unicamente, a presença residual do contrato de arrendamento, sinalizando que uma época histórica de Direito Agrário de fato encerrou-se. ${ }^{53}$

Com efeito, nos países da Comunidade Econômica Européia, optou-se pela admissão de um único tipo de contrato - o arrendamento - a que é reduzido todo contrato agrário. As diferenças, as particularidades de cada contrato agrário, ressalvado o respeito às normas de ordem pública, podem existir, mas se reduzem ao tipo único, o arrendamento.

Trata-se de orientação que determinou modificação nas várias legislações para se adequar a um padrão único para os países comunitários.

No passado, admitiu-se que o direito agrário era o direito dos contratos agrários e com tal enfoque justificou-se a natureza do direito agrário. As condições que justificaram tal entendimento desapareceram com o caso da concepção liberal de economia agrícola e com a progressiva restrição da expressão da autonomia da vontade dos particulares.

Há uma tendência no plano do direito positivo, por exemplo, na Itália, onde se registra um empobrecimento sensivel dos tipos contratuais aos quais era possivel recorrer: climinados em um primeiro tempo os contratos atípicos e suspensa, mais ou menos definitiva e completamente, a categoria dos contratos associativos como a parceria, apresentando-se a nova sistematização legislativa dominada pelo princípio da conversão legal dos contratos associativos em curso e pelo princípio da redução legal ao arrendamento de todo contrato de estipulação futura de concessão de terra. $^{54}$

Outro fenômeno importante reside no fato de o contrato agrário servir, sempre mais raramente, de meio para a constituição da empresa, o que se comprovou na Itália, com a grande difusão da terra cultivada diretamente pelo proprietário, o que decorreu da extensa ação de incentivo público. ${ }^{55}$

53. MASSART, Alfredo. Problemas actuales de la dogmática.... p. 66.

54. CARROZZA. Antonio, ZELEDÓN, Ricardo Zeledón, op. cit. p. 33.

55. Id. Ihid op. cit. p. 33. 
Apesar de tal fenômeno o contrato representa um instituto ainda importante para o direito agrário: são numcrosos os contratos que se podem denominar agrários: contratos de financiamento, contratos de consórcio e contratos agroindustriais. ${ }^{56}$

Conversão sob um perfil político e econômico é a expressão de uma tendência planificada que acaba por comprimir a autonomia das partes, a paridade de tratamento entre essas, a sua liberdade econômica. ${ }^{57}$

3. Conversão dos contratos agrários.

A tendência de conversão do legislador italiano, em verdade, é verificável em quase lodos os paises da Europa ocidental. que procuram uma acomodação moderna econômico-social da agricultura. Nestes países o arrendamento foi considerado como o instrumento ideal para potencializar as unidades produtivas e para contribuir na transformação dos sistemas agrários tradicionais, os quais há tempo não encontravam mais aderência com a realidade econômica em transformação. ${ }^{58}$

$\mathrm{O}$ crescente processo de industrialização das unidades produtivas impunha mudanças na disciplina dos contratos agrários.

A conversão legal e o planejamento se movimentaram, pois, em sintonia não apenas para atuar mera modificação na acomodação negocial dos contratos agrários, mas também para fornecer o deslocamento do poder fundiário tradicional dos concedentes aos concessionários. ${ }^{59}$

A tipificação, a transformação, a conversão legal são a expressão de um projeto unitário do legislador italiano. o qual floresce uma nova face da sociedade rural. Este é um modelo inovativo e reformador que atuou, não obstante as resistências daqueles que viram nas terras apenas bens econômicos - produtivos sobre os quais realizar investimentos e não também bens socialmente úteis.

O fundo como unidade produtiva é um bem social de relevância coletiva e enquanto tal constitui o objeto de um contrato.

56. Id. Ibid. op. cit. p. 33.

57. SALARIS. Fernando, op. cit. p. 41.

58. Id. Ihid. op. cit. p. 33-42.

59. Id. Ibid. op. cit. p. 43. 
O contrato agrário é um contrato especial, configurado de maneira que o concedente veja progressivamente reduzidos os próprios poderes de decisão e de destinação econômica em vantagem do concessionário. $\mathrm{cm}$ harmonia com o processo de desenvolvimento da economia agrária. ${ }^{60}$

Com a conversão legal do contrato agrário, as partes são obrigadas por vontade supcrior da lei a reconhecer-se numa combinação típica, isto é, numa espécie contratual julgada mais idônea para atuar aquelas finalidades que o cuntrato de outro modo não poderia realizar, por exemplo, contribuir no controle da iniciativa econômica das partes, em sintonia com as exigências do planejamento, especialmente do empresarial. ${ }^{61}$

A conversão constitui uma aplicação do princípio da conservação do contrato. A conversão legal transforma o contrato na sua inteireza como se expressara validamente a autonomia das partes antes da intervenção do legislador: substitui os efeitos originariamente procurados a yue as partes se encontravam obrigadas a observar por outros novos, mesmo não os tendo desejado no momento da estipulação do contrato conversivel. ${ }^{62}$

O contrato conversível está unido ao contrato convertido pela vontade legislativa, considerado mais idôneo para realizar as principais finalidades econômicas e sociais que o ordenamento juridicu se propõe a atuar: a redução dos contratos agrários e a reorganização das unidades produtivas. ${ }^{63}$

A conversão legal não alcança o contrato agrário mas "a relação relativa entre duas situações subjetivas em conflito, aquela, por exemplo, do meeiro e outra do parceiro outorgante" Verifica-se, apenas, uma modificação legal do título, que se transforma $\mathrm{em}$ troca ou arrendamento, em relação ao contrato inicialmente associativo. $^{64}$

60. Id. Ibid. up. cit. p. 44.

61. Id. Ibid. op. cit. p. 44-45.

62. Id. Ibid. op. cit. p. 45-46.

63. Id. Ibid. op. cit. p. 46.

64. Id. Ibid. op. cit. p. 4 ? 
A natureza jurídica da conversão agrária, mesmo como instituto novo, deve ser definida com aderência às finalidades conômico-sociais a que sce dirige, c c não voltada necessariamente "a esquemas normativos e conceituais conhecidos" 65

Na conversão agrária é necessário que o contrato conversível não mais corresponda a critério do legislador à sua correlação com as funções sociais e econômicas, que através dele são procuradas nas relações agrárias.

A ausência de proteção legislativa do contrato baseia-se não num vício de um elemento negocial essencial, mas prevalecentemente em motivações políticas, sociais ou econômicas que determinam ao legislador excluir um contrato agrário entre aqueles merecedores de tutela por parte do ordenamento e como tais aptos a sobreviver. $^{66}$

A conversão legal agrária não é apenas um dos tantos instrumentos em que a intervenção do legislador pode se exprimir. A conversão legal responde a uma lógica particular, vez que incide sobre a dinâmica dos contratos e ao mesmo tempo sobre a ordem institucional da propriedade e da empresa. ${ }^{67}$

A tradicional correspondência entre esquema normativo e tipo sócioeconômico é. assim, violada e o arrendamento é estabelecido como regra exclusiva para todas aquelas relações em que seja verificável um conflito entre a renda fundiária, de uma parte, e a empresa agrícola de outra. ${ }^{68}$

A conversão legal agrária apresenta uma peculiaridade, porquanto concerne à qualidade da função social e econômica que o legislador procura através dela (conversão legal).

A política de intervenção pública que atua deste modo consiste na realização de uma atividade produtiva desenvolvida. normalmente, no âmbito das relações agrárias, através de uma empresa agrícola. Uma empresa que neste caso se origina por um contrato de arrendamento de fundo rústico e não por contratos

65. Id. Ibid. op. cit. p. 47.

66. Id. Ibid. op. cit. p. 49.

67. Id. Ibid. op. cit. p. 50.

68. Id. Ibid. op. cil. p. 50. 
associativos que o legislador italiano julgou que não mais correspondiam às funções sociais e econômicas que a ele se propunha alcançar. ${ }^{69}$

Subsiste um nexo de reciprocidade entre a conversão legal e a transformação.

A conversão legal transforma o contrato na sua inteireza onde já se expressara validamente a vontade das partes.

A conversão legal, do mesmo que a transformação, comprime a autonomia privada, substitui os efeitos do contrato por aqueles de um contrato totalmente diferente. decidido pelo legislador, que o reputa mais idôneo do que o originário para realizar aquelas finalidades econômico-sociais. ${ }^{70}$

A transformação constitui, pois, como a conversão, um instrumento jurídico típico da intervenção pública, necessário não apenas para reformar os contratos agrários, mas para planejar a agricultura sob o aspecto econômico. ${ }^{71}$

A transformação em arrendamento objetivou alcançar escopos econômicos - produtivos de grande relevância social, direcionados não apenas a garantir uma estrutura unitária no âmbito das relações agrárias mas, também, estabelecer relações sociais équas e uma exploração mais racional das unidades produtivas com uma acomodação eficaz da empresa.

Foi assim reforçada uma peculiaridade comum, seja para a transformação como para a conversão: a política intervencionista do legislador voltada ao potencial da atividade produtiva através da metamorfose criativa de determinados contratos e a limitação da autonomia contratual. ${ }^{72}$

A conversão legal do contrato associativo depende da aceitação formal do concessionário, ao contrário da proposta por este formulada que produz, ipso iure, a conversão do contrato originário em arrendamento do fundo rústico, substituídos os pressupostos subjetivos e objetivos.

69. Id. Ibid. p. 51. O art. 25 da Lei n. 203 de 1982 revela que o legislador italiano julgou que os contratos associativos passaram a apresentar tal limitação. $\mathrm{O}$ art. 36 da mesma lei impede a possibilidade de se constituir novas formas societárias.

70. Id. Ibid. op. cil. p. 59.

71. Id. Ibid. op. cit. p. 59.

72. Id. Ibid. op. cit. p. 62-63. 
Quanto a parceria, quando o concedente é empresário a título principal ou dá uma contribuição adequada na co-direção da empresa, então é necessário que as partes estcjam num plano de paridade, sendo ambos trabalhadores e como tais merecedores de tutela reforçada. Ainda assim se pode falar em direito potestativo do concessionário à conversão legal. À sua proposta, em regra, não deve corresponder o assentimento do concedente à conversão em arrendamento. ${ }^{73}$

O concedente receberá contraprestação em dinheiro.

Esta orientação nas estruturas agrárias está em consonância com novas regras ditadas pelas diretivas da Comunidade Econômica Européia. A inclinação do legislador italiano para o arrendamento encontra confirmação exata na legislação dos paises aderentes a C.E.E. É, com efeito, possivel encontrar analogias entre a disciplina dos institutos que indicamos, contidos na Lei n. 203/82, e aquela dos institutos dos países que integram a C.E.E., que apresentam linhas evolutivas comuns em matéria de arrendamento de fundos rústicos. A intervenção pública está presente constantemente na disciplina das vicissitudes agrárias, isto se revela não apenas quando favorece a propriedade direta cultivada, colocando o empresário nas condições de gerir o fundo, mas de modo especial, quando integra a disciplina do contrato agrário com o auxilio de instrumentos de interesse público, com o potenciamento da empresa agrícola. ${ }^{74}$

Há mais, atribuir um controle sobre a formação do contrato; garantir a continuidade do cultivo da terra por parte do arrendatário; conceder ao arrendatário, através da regulamentação da remuneração pelo arrendamento, a possibilidade de retirar do próprio trabalho uma entrada suficiente para uma vida digna; atribuir ao arrendatário uma indenização pelas benfeitorias extra-executadas no fundo; criar procedimentos formais que resolvam, com celeridade, as controvérsias eventuais entre as partes, são princípios comuns aos países aderentes da Comunidade Econômica Européia. $^{75}$

É importante ressaltar que da prática de imposição de cláusulas contratuais passou-se à imposição de tipo contratual.

A conversão legal possui a força de um verdadeiro e próprio comando juridico pelo qual a posição do concedente deve ceder frente ao concessionário.

73. Id. Ibid. op. cit. p. 67.

74. Id. Ibid. op. cit. p. 72-73, nota 57.

75. Id. Ibid. op. cil. p. 73, nota 57. 
A conversão em arrendamento a pedido de uma das partes apresenta-se com aspectos comuns com a recondução ao arrendamento, mas há muitas dilurenças. Contratos tradicionalmente contrapostos ao arrendamento tornam-se transformáveis em arrendamento. Mais uma manifestação de dirigismo e a favor do concessionário. A declaração do concessionário basta para transformar, ınquanto a declaração do concedente necessita da adesão alheia. ${ }^{76}$

A doutrina chama de transformação aquilo que scria, segundo a lei, a conversão. A conversão, melhor conversibilidade, dcixa o beneficiário livre para avaliar a conveniência da passagem para o arrendamento, avaliação irrepreensível sobre a qual se pode visualizar uma infinidade de peculiaridades do caso concreto. ${ }^{77}$

A recondução não se pode interpretar como reconduzibilidade porque aqui a aplicação das normas sobre arrendamento é automática, verifica-se por força da lei. $^{78}$

No direito italiano reservou-se o instituto da conversão legal para atuar sobre os contratos agrários existentes por ocasião do advento legal da Lei n. 203/82, enquanto a recondução legal incide, automaticamente, sobre os contratos agrários aperfeiçoados após o advento a referida Lei.

Quanto aos limites da derrogação dos pactos: existe um arrendamento amplamente suscetível de ser modelado, caso por caso, graças à autonomia contratual "assistida" pelas partes colocadas em igualdade de posições, assistida pelas organizações profissionais. Contudo existe a proibição de contratur parceria. ${ }^{79}$

A legislação suprimiu a prorrogação legal pela opção por um prazo mínimo, porém extenso, de quinze anos, o qual poderá ser objeto de denúncia. Com isso existe uma complementariedade entre possibilidade de desfazer-se do concessionário e possibilidade de fazê-lo aceitar cláusulas mais filoconcedentes. ${ }^{80}$

A redução dos contratos agrários coloca-se como gênero em relação às espécies da tipificação: transformação, conversão c recondução.

76. FERRERO, Enzo, op. cil. p. 19.

77. Id. Ibid. op. cit. p. 20.

78. Id. Ibid. op. cit. p. 20.

79. Id. Ibid. op. cit. p. 33. Trata-sc do art. 45 da Lei n. 203/82.

80. Id. Ibid. op. cit. p. 37. 
A "reductio ad unum" dos tipos contratuais induziu o legislador a promulgar. também, o art. 27 da Lei n. 203. que contém a disciplina da recondução de todos os novos contratos de concessão de fundos rústicos ao arrendamento, com o que se confirmou a "exclusiva centralidade do arrendamento no quadro geral dos contratos agrários" 81

Quando, após a entrada cm vigor da Lei n. 203, um contrato agrário cessa e as partes entendiam estipular um contrato agrário de concessão. deverão aplicar a técnica da recondução ao arrendamento, a qual constitui o momento conclusivo do "iter" de redução dos contratos agrários. ${ }^{82}$

Fernando Salaris esclarece que o contrato de arrendamento revela sua superioridade e reaparição como contrato de concessão ideal, ademais, o contrato de arrendamento de fundo rústico sofreu uma metamorfose profunda, de "ato de autonomia da vontade do contratante particular para contrato legal com uma tipização do conteúdo e da causa impelida ao extremo". 83

A recondução reforça uma escolha com a qual se reconhece que o arrendamento é o tipo contratual privilegiado para desenvolver "a função social atribuida ao contrato agrário (que é função mista de tutela da empresa, especialmente se empresa cultivadora direta e de tutela do contraente mais fraco ou assim presumido, enquanto fornecedor para a empresa de prestação de trabalho)" 84

A técnica da recondução ao arrendamento objetiva o mesmo fím das outras espécies (tipização, transformação. conversão). isto é a aplicação generalizada de um contrato agrário, que é o mais adequado, no possivel, às exigências da agricultura e apresenta traços particulares que o distinguem suficientemente de qualquer outro contrato.

$\mathrm{Na}$ recondução, porém, prevalece o automatismo rígido e indiferenciado previsto pelo legislador, pelo qual as partes devem estipular um contrato que tenha por objeto um fundo rústico ou que, entre suas prestações, exista

81. SAI ARIS, Fernando, op. cit. p. 127-128.

82. Id. Ibid. op. cit. p. 128.

83. Id. Ibid. op. cit. p. 129 cita CARROZZA, Antonio, Diritto agrario e costituzione in Rivista di Diritlo Agrario. 1985, I, p.8

84. Id. Ibid. op. cil. p. 129 e 130. Entre aspas a citação de CARROZZA, Antonio, "Lariconchcione all 'affitto dei contratti agrari di concessione", p. 319. 
um fundo rústico. As partes devem observar a regulamentação do arrendamento, sem que haja espaço para a faculdade de escolha, mesmo o direito da possibilidade de recorrer a alguma das exceções da técnica de recondução. ${ }^{85}$

$\mathrm{O}$ alcance da recondução é tal que todos os contratos agrários de concessão nela se inserem, mesmo aqueles com elementos de contrato associativo os quais por expressa disposição legal produzem em cada caso efeitos do arrendamento de fundo rústico - vez que é vedada sua sobrevivência. ${ }^{86}$

$O$ instituto da recondução aplica-se tanto em eventualidade de cultivador direto como de cultivador não direto ou arrendamento "capitalístico"

A legislação italiana, por exemplo, diferenciava o cultivador direto do não cultivador direto, mas tal situação sofreu uma atenuação, parecendo evidente e pacífico em doutrina o atenuar-se da disparidade de tratamento entre contraente cultivador direto e contraente não cultivador direto. O cultivador direto se privilegia quanto ao montante da remuneração e nas pequenas benfeitorias. ${ }^{87}$

4. Convertibilidade dos contratos associativos.

A Lei italiana n. 203, de 1982, introduziu uma orientação para a existência de um "tipo único de contrato agrário" 88

A matéria pode ser exemplificada com a "conversibilidade em arrendamento" dos contratos associativos, por exemplo, a parceria a pedido de uma das partes. A conversão em arrendamento estende-se aos chamados contratos de coparticipação agrária.

Quando se tratar de contrato agrário tendo por objeto a concessão de fundos rústicos ou entre suas prestações haja concessão de fundos rústicos, caracterizar-se-á a recondução do arrendamento.

A primeira eventualidade se tipifica quando o contrato existia por ocasião da entrada em vigor de referida lei. enquanto que a segunda eventualidade

85. Id. Ibid. op. cil. p. 130.

86. Id. Ibid. op. cit. p. 130-131.

87. FERRERO, Enzo, op. cit. p. 58-59.

88. A matéria está regida pelo art. 25 da Lei n. 203/82, aplica-se aos contratos então vigentes. 
pressupõe aperfeiçoado após a entrada em vigor da Lei n. 203. Portanto. a primeira eventualidade é de conversão e a segunda de recondução. ${ }^{89}$

Com o tipo de recondução, a hegemonia do arrendamento avançou demais. Enzo Ferrero explica o significado do instituto com a imagem de alguém que atua para fugir a algo desagradável, mas em vão recai, sempre. neste quid chamado arrendamento: é reconduzido a este tipo. ${ }^{90}$ Trata-se de norma de ordem pública.

É irrelevante que o contrato se caracterize como de arrendamento para que assim se o considere; basta que objetive uma concessão de fundo rústico ou que, entre suas prestações. haja concessão de fundo rústico. A norma "reconduz" ou "dirige" para o arrendamento prescindindo, completamente, do específico intento negocial das partes."

Scgundo Enzo Ferrero, raramente o direito italiano alcançou tal ponto de dirigismo contratual. Esta técnica procede da relação concretamente pelas partes, antes que tipo contratual.

Lembra que a "recondução, prevista no art. 27 da Lei n. 203, de 1982, é uma eventualidade de "inserção automática de cláusulas (também) em substituição das cláusulas chamadas disformes colocadas pelas partes, nos termos do art. 1.339 do Código Italiano". Não há como frustrar o arrendamento. ${ }^{92}$

Nos contratos associativos conversiveis em arrendamento, as partes se encontram em situação de disparidade. A vontade do concessionário, em regra, prevalece sobre a do concedente; este é colocado numa situação de sujeição em relação ao concessionário, legitimado no direito potestativo da conversão. O legislador opera com base em princípio superior de justiça econômico-social, com o fím de estabelecer o equilibrio entre as várias categorias de trabalhadores e tutela valores como o trabalho. ${ }^{93}$

O contrato de arrendamento de fundo rústico foi valorizado exatamente como o instrumento idcal de mediação entre propriedade e trabalho, como o único

89. A recondução aplica-se aos novos contratos e se aperfeiçoa opu legis.

90. FERRERO. Enzo, op. cit. p. 14-15.

91. Id. Ibid. op. cit. p. 14-15.

92. Id. Ibid. op. cit. p. 16.

93. SALARIS, Femando, op. cit. p. 77. 
tipo contratual adequado às exigências de uma composição modema das estruturas agrárias. $^{94}$

A relação jurídica agrária não mais se configura como associativa e se estrutura como um contrato de troca, em que se revela de um lado a função do concedente que recebe a renda, de outro o concessionário, que exerce todos os poderes de gestão atribuídos ao arrendatário, como reconhecimento da prevalência econômica que o seu trabalho adquire com relação ao capital fundiário outorgado pelo concedente. $^{95}$

A redução dos contratos agrários tornou-se necessária, também, para dar prevalência aos novos critérios técnicos e econômicos sobre aqueles tradicionais, de maneira que o titular da unidade produtiva (o concessionário) pudesse encontrar a sustentação na própria atividade, conforme as novas exigências sócio-econômicas em que se encontra inserido. ${ }^{96}$

As diretrizes comunitárias exigem, para que se opere a conversão dos contratos associativos, a existência de uma unidade produtiva eficiente, o que se configurará quando possa obter um limite mínimo de exercício de empresa agrícola, que o legislador considere ótimo. ${ }^{97}$

As modificações a título de adaptação ao direito comunitário existem, também, quanto à terminologia das partes contratantes quando se tratar de atividade agrária.

A terminologia nos contratos agrários tem usado as expressões "concedente" e "concessionário", portanto mais genérica do que arrendante arrendatário, parceiro - outorgante e parceiro - outorgado, e nos sistemas, como o brasileiro, que admite a existência de contratos atípicos ou inominados, optar-se-ia por uma uniformidade terminológica.

Contudo, a expressão "concedente" engloba várias categorias, pois pode não coincidir necessariamente com "proprietário" e sem razão, às vezes, a contraparte. a trabalhadora, é chamada de "proprietário" 98

94. Id. Ibid. op. cit. p. 77.

95. Id. Ibid. op. cit. p. 81.

96. Id. Ibid. op. cit. p. 107.

97. Id. Ibid. op. cit. p. 107.

98. FERRERO, Fnzo, op. cit. p. 7-8. 
A terminologia utilizada é "parte concedente" e "parte concessionária", mas existe falta de homogeneidade verificável não apenas na categoria dos concessionários pluricodificada com várias categorias jurídicas com tratamento diferenciado, mas também situação similar ocorre quanto aos "concedentes" 99

\section{Contrato Agroindustrial.}

A categoria dos contratos agroindustriais é indiscutivel quanto à sua existência, a qual é fácil de sustentar porque a sua configuração ocorre continuamente na prática contratual, a despeito da dificuldade em obter unidade sob o perfil dogmático jurídico.

Para Ricardo Zeledón Zeledón, o contrato agroindustrial pode ser identificado, em sentido amplo, em todos os acordos entre empresários agrícolas, zootécnicos e fitotécnicos. e empresários comerciais, industriais ou comerciantes, através de uma integração vertical das atividade agrícola e comercial, da qual nascem obrigações recíprocas da mais variada indole, tendentes, entre outras, a produzir na forma associada um determinado produto com características determinadas, sob a gestão do empresário agrário na agricultura, recebendo em contraprestação serviços e assistências do empresário comercial além do pagamento. ${ }^{100}$

Completa o referido autor que o contrato pode nascer proveniente de um acordo entre um grupo de empresários agrícolas com um comercial, ou da representação dos primeiros com grupos de empresários comerciais - sendo neste caso identificados como acordos interprofissionais - pelo que se os identifica como contratos de integração vertical, que se concretizam logo em forma individual entre uns e outros. gerando-se entre uma ampla gama de obrigação de fazer. ${ }^{101}$

O contrato agroindustrial é um contrato atípico, daí a pertinência da fixação de sua natureza jurídica, do seu enquadramento numa das categorias de contratos: civil, agrário, industrial ou comercial.

99. Id. Ibid. op. cit. p. 9. Lisa as expressōes filoconcedente e filoconcessionário para se referir a institutos que previlegiam uma ou outra categoria.

100. ZELEDÓN, Ricardo Zeledón e CARROZZA, Antonio, Teoria general e institutos de derecho ugrário, ob. cit. p. 312-313.

101. Id. Ibid. op. cit. p. 
A conclusão a que se deva chegar é a da existência de necessidade de caracterizar o contrato sobre bases dogmáticas do direito agrário, mas de qualquer modo, ainda inexistindo um contrato típico, Ricardo Zeledón Zeledón ressalta que em uma complexidade de relações haverá um caráter de contrato misto. ${ }^{102}$

O substrato das relações se origina precisamente no ciclo biológico e a integração vertical se dirige principalmente ao mercado agroalimentário.

$O$ contrato agroindustrial caracteriza-se tendo presente quatro aspectos: a) a atividade agroindustrial é conexa à de produção agrária: b) o contrato agroindustrial é um contrato típico de exercício da empresa agrária: contrato associativo; c) complexidade da causa no contrato agroindustrial; d) urgência na sua institucionalização e conceitualização. ${ }^{103}$

Antonio Carrozza elucida que o estatuto da matéria deveria se centrar no problema se o contrato agroindustrial é ou não um contrato agrário. Após indicar a existência de contratos para a empresa, ou seja, contratos agrários em sentido estrito e tradicional, refere-se à outra categoria, dos contratos da empresa agrária. Expõe que a estes últimos recorre o empresário agrícola, titular de uma empresa já constituída e em fase de exercício, para obter o financiamento da empresa, para conseguir mão de obra, para se assegurar contra os riscos típicos da agricultura, etc. Recorre a estes contratos, também, para vender os produtos colhidos ou ainda em curso de maduração: este é o ponto que nos interessa. ${ }^{104}$

$O$ ilustre Mestre ensina que o contrato agroindustrial serve ao empresário agrário essencialmente para realizar o fim de alienação dos produtos.

Considerando que o acordo com a empresa industrial de transformação se verifica antes da colheita, não se pode negar que estamos diante da causa de venda de uma coisa futura (os frutos do fundo em estado verde ou, todavia, não nascidos). Não se equivocou, pois, quem aproxima este contrato deste subtipo de venda. ${ }^{105}$

Antonio Carrozza explica, por outro lado, que não devemos esquecer que a venda dos produtos e sua colocação no mercado constitui uma fase da atividade desenvolvida pelo empresário agrário. Trata-se, precisamente, de uma atividade

102. Id. Ibid. op. cit. p.

103. Id. Ibid. op cit. p. 319-320.

104. Id. Ibid. op. cit. p. 323-324.

105. Id. Ibid. op. cit. p. 323-324. 
"conexa" (segundo a terminologia do art. 2.135 do Código Civil Italiano) e como tal absorvida pela órbita da empresa agrária e sujeita ao seu estatuto. É claro, então, que significa entregar-se a abstrações examinar a venda de coisa futura sem colocá-la em relação com a atividade de produção agrícola, e sem envolver, por conseguinte, o conceito de empresa agrária.

A seguir, o especialista completa seu pensamento afirmando que é necessário esclarecer, imediatamente, que uma tal qualificação resulta parcial: o contrato estipulado sob o nome de contrato agroindustrial é algo mais que um contrato obrigatório de venda porque à função típica deste contrato - obrigar-se a transferir a propriedade de certos bens em troca do preço correspondente * somam-se, e algumas vezes se sobrepõem, outras causas contratuais. Pode-se dizer, em resumo, que nos encontramos frente a um contrato de causa mista, com todas as consequêencias referentes ao plano interpretativo. ${ }^{106}$

Descrever estes elementos causuais agregados com um número definido não parece possível, por eles serem estritamente variáveis de uma "fattispecie" concreta a outra, e segundo Antonio Carrozza informa, a casuistica é extremamente rica conforme revelações dos estudiosos. Isso explica a atitude do direito positivo francês, o qual, sem entrar em pormenores, limita-se a sustentar como caracterizante a presença de uma multiplicidade de obrigações recíprocas entre as partes. Antonio Carrozza critica esta atitude, entendendo-a nada satisfatória sob o ponto de vista de uma classificação cientifica, por se circunscrever a verificação de um caráter que pertence a qualquer contrato com prestações recíprocas. Daí o incentivo a se completar a "fattispecie" legal recorrendo-se a elementos extra-legais extraidos da experiência econômica. ${ }^{107}$

Passemos a análise de algumas caracteristicas do contrato agroindustrial, formuladas por Ricardo Zeledón Zeledón.

a) a atividade agroindustrial é conexa a de produção agrária:

$\mathrm{O}$ contrato agroindustrial permite entrever uma certa relação de conexão entre o empresário agrário e o empresário comercial, vez que o primeiro recebe não apenas uma contraprestação em dinheiro, mas também o complexo das obrigações recíprocas o permite adquirir certos direitos provenientes da própria

106. Id. Ibid. op. cit. p. 324.

107. Id. Ibid. op. cit. p. 324-325. 
industrialização de seus produtos. Esta situação encontra paralelo ao se reputar conexas às atividades do empresário agrário àquelas de transformação, industrialização ou comercialização de seus produtos.

Encontramos a agricultura na base da integração vertical e sobre ela se encontra o empresário comercial realizando atividades industriais e comerciais, não se podendo entender factível a realização destas últimas sem a existência da primeira, de onde se origina o ciclo produtivo. Dentro desta contextura - e ainda quando se afirme sua atipicidade - o contrato agroindustrial permite uma qualificação dentro do contrato agrário, como ensina Ricardo Zeledón Zeledón. ${ }^{108}$

b) $O$ contrato agroindustrial é um contrato típico de exercício da empresa agrária - Contrato associativo.

$\mathrm{Na}$ distinção entre contratos agrários para a empresa - - os destinados a constituição da empresa agrária - e aqueles da empresa ou assim denominados de exercício da empresa agrária, o contrato agroindustrial entra na segunda categoria, pois são empresas já constituídas que outorgam eficácia para a satisfação de um fim.

Além disso, como ensina Ricardo Zeledón Zeledón trata-se, claramente, de contrato associativo (não de intercâmbio: como o seria, pura e simplesmente, na venda de produtos agrícolas), porque há empresários agrícolas e comerciais, resultante das obrigações múltiplas de fazer, interacionando-se, obtendo benefícios mútuos. ${ }^{109}$

Antonio Carrozza, após considerar o contrato agroindustrial como contrato com causa mista, esclarece que apresenta uma pluralidade de causas, porém, uma delas pode se apresentar preeminente e servir em certo sentido de liame das outras: uma supercausa, em suma, identificável no fim comum de realizar uma coordenação de atividades pertencentes a duas empresas distintas e com natureza diferente.

Estas considerações, conclui Antonio Carrozza, desobstruem o caminho para se qualificar o contrato agroindustrial como um contrato (agrário) associativo. ${ }^{110}$

108. ZELEDÓN, Ricardo Zeledón e CARROZZA, Antonio, Teoria general e institutos de derecho agrario, op. cit. . . 319.

109. Id. Ibid. op. cit. p. 319.

110. CARROZZA, Antonio e ZELEDÓN, Ricardo Zeledón, Teoria general c institutos de derecho agrario, op. cit. p. 326. 
Ao se falar em contrato associativo deve-se esclarecer que a terminologia é adequada e não se relaciona com o problema da conversão do contrato agrário em um único tipo, como já se examinou.

c) Complexidade da causa no contrato agroindustrial.

A empresa, sendo a causa do contrato, não se poderia afirmar na existência exclusiva de uma causa agrária, mas essa causa adquire caráter misto enquanto na base do contrato se encontram duas empresas que exercem tipos diferentes de atividades e assim a causa poderia ser agrária e industrial, agrária e comercial, ou com acerto: agrária, industrial c comercial.

O contrato agroindustrial, como forma econômica emergente, passou a normatizado, convertendo-se em verdadeira categoria jurídica. "II

d) Urgência na institucionalização e conceitualização do contrato agroindustrial.

A institucionalização dos contratos agroindustriais é de urgência inadiável, quer sc os conceba em forma unitária ou estabelecındo diferentes regimes jurídicos, conforme as nccessidades próprias da atividade em cada uma das suas ocupações, seja pela importância dos produtos na economia nacional, ou para dar vida a formas contratuais consueludinárias, isto porque o momento em que vive a agricultura requer instrumentos sólidos que superem sua concepção tradicional e a levam rumo ao progresso. ${ }^{112}$

Ricardo 7eledón Zeledón conclui, quanto aos contratos agroindustriais, que naturalmente a urgência na institucionalização caminha aparelhada à necessidade de delimita-los conceitualmente, e neste campo os conceitos elaborados pela teoria geral do direito agrário deveriam servir - melhor que outros - para juridicializar o contrato agroindustrial como forma de integração vertical na agricultura. ${ }^{113}$

Os caracteres fisionômicos da relação jurídica consubstanciada em contrato agroindustrial não se exaurem na alienação de uma quantidade determinada de produtos com características bem individuadas de um lado c na sua aquisição por um correspectivo em dinheiro de outro. Além da relação meramente comutativa, as

111. ZELEDÓN. Ricardo Leledón e CARROZZA, Antonio, Teoria general e institutos de derecho agrario, op. cil. p. 319.

I12. Id. Ibid. op. cil. p. 320.

113. Id. Ibid. op. cil. p. 320. 
partes originam uma relação jurídica composta por múltiplas obrigações reciprocas e é nesta reciprocidade, que surge a contraprestação de um preço pela aquisição de produtos agrícolas, que se visualizou o traço peculiar dos contratos agro-industriais. ${ }^{114}$

Para Massimo Confortini e Attilio Zimatore, o contrato agro-industrial, além de produzir efeito translativo da propriedade dos frutos do fundo, gera a cargo das partes numerosas obrigações correspectivas: o agricultor é normalmente obrigado a seguir técnicas de cultivo, às vezes predeterminadas no próprio contrato, outras vezes impostas, no curso do desenvolvimento da relação jurídica pelo adquirente; em muitos casos o agricultor deve empregar scmentes, estrumes, antiparasitas fornecidos pelo adquirente (por um preço determinado que será sucessivamente deduzido do pagamento pela transferência do produto), ainda é obrigado a realizar as operações de semeadura e colhcita conforme modalidades e épocas fixadas pelo outro contraente; freqüentemente é obrigado a utilizar, para a transferência da mercadoria para o local de entrega, recipientes fornecidos pelo adquirente e observar normas minuciosas para a embalagem. Em numerosos casos, enfïm, o agricultor está obrigado à empresa de transformação e de comercialização por um pacto de exclusividade. ${ }^{115}$

Os contratos agroindustriais têm como sujeitos legitimados para a conclusão dos acordos interprofissionais, de um lado, as associações dos produtores ou as uniões pertinentes reconhecidas e, de outro lado, as associações ou agrupamentos de empresas de transformação ou de comercialização. ${ }^{116}$

Os contratos agroindustriais podem consistir em contratos individuais de cultivo e cessão de produtos agrícolas. Os caracteres deste tipo contratual ainda inominado são: oneroso, consensual, forma livre, não intuitu personae; há dúvidas se o legislador tenderá para contrato com efeitos reais ou, puramente, obrigacionais ou se estará tipificado como contrato "a consenso antecipato" 117

Discute-sc, em nível de proposta legislativa de regulamentação do contrato agroindustrial, se as obrigações a cargo do empresário agrícola encontram limites na força maior e pelo menos formulou-se uma orientação no sentido de que o

II4. CONFORTINI, Massimo e ZIMATORE, Attilio, op. cit. p. 224. Quanto ao elcmento reciprocidade se referem a contribuição de Jean Megret e Jacques Prevault.

115. Id. Ibid. op. cit. p. 224.

116. Id. Ibid. op. cil. p. 228.

117. Id. Ibid. op. cil. p. 231. 
devedor livra-se da obrigação de adimplir, exclusivamente, se a eventualidade de força maior se tenha verificado na primeira fase do ciclo produtivo e desde que não seja possível nova semeadura ou transplante. ${ }^{118}$

Soviética. ${ }^{119}$

O contrato agroindustrial é usado entre empresas agrárias na ex-União

A expressão agroindustrial aparece no Estatuto da Terra, mas não se conecta ao instituto contrato agroindustrial. $\mathrm{O}$ art. 92 da referida Lei prevê a parceria agroindustrial a qual é definida no art. $5^{\circ}$, inciso, III, do Decreto n. 59.566, de 14 de novembro de 1966.

Para concluir este capilulo, impõe-se saber se o âmbito do contrato agroindustrial se alarga com a noção difundida por alguns de um Direito agroalimentar.

Ao tratarmos de agricultura analisando a matéria sob vários ângulos, impõe-se distinguir a concepção "pura" de direito agrário do direito ambiental e direito agroalimentar.

Nota-se na doutrina agrarista de certos países, especialmente em lingua espanhola, inclinação em direção a preservação dos recursos naturais e ao direito agroalimentar.

Parte da doutrina agrarista italiana se posiciona com fidelidade a favor da manutenção de uma concepção "pura" do direito agrário e de seu objeto e está induzida a afastar (ou pelo menos manter à margem da matéria jusagrarista) as sugestões daqueles que sustentam estar em curso ou, até, já estaria muito avançada a transformação do direito agrário - concebido como o complexo de normas que disciplinam a produção agrícola e a atividade pertinente - em um direito da natureza, dominado pela preocupação ecológica e forjado na medida desta (e que se poderia denominar, também, direito ambiental), ou em um direito da alimentação concebido de modo a abraçar todos os fenômenos da produção, e conjuntamente aqueles pertinentes à transformação industrial dos produtos da terra e da criação.

Para exemplificar, o jusagrarista argentino Eduardo Pigretti é expoente da corrente de seu pais que valoriza as reservas naturais e delineia os critérios e

118. Id. Ibid. op. cil. p. 232.

119. BELJAEVA, Z. S. II contratto come forma giuridica di regolamentazione dei rapporti economici nel complesso agro-industriale (APK), Rivista di Diritto Agrario, v. 67. 1988, p. 221. 227. 
princípios que embasam o direito ambiental; o jusagrarista espanhol Alberto Ballarin Marcial procura demonstrar que o direito agrário convencional está na iminência de ser absorvido pelo direito agro-alimentar: e pode ser indicado Giulio Vignoli que aponta a hipótese de um direito sanitário - veterinário da agricultura ao qual pertenceria o direito alimentar ou vice-versa. ${ }^{120}$

O direito agroalimentar na concepção de Alberto Ballarín Marcial é "um sistema de normas que regulam a atividade pública e privada relativa à agricultura e alimentação. À conservação da natureza e a melhoria das condições do ambiente rural" O criador da orientação explica que se trata de introduzir na definição o termo alimentação e propor que. por conseqüência, este sistema de normas se denomine direito agro-alimentar, vez que os dois pólos em que se baseia seriam, de um lado, a relação homem-terra face a produção de alimentos e matérias primas numa atividade agrícola strictu sensu e, de outro lado, a alimentação: fenômeno, cste último que abrange não apenas a agricultura, mas, também, a pesca, a criação de ostras, a aquacultura, a criação de animais e. em geral a produção de carnes e de vegetais "sem terra" incluida a extração de petróleo. Alberto Ballarín Marcial referindo-se à conservação da nature za e do ambiente rural, não obstante sua impurtância, assevera ter relevo menor e, pois, não aparecem, diretamente. no vocábulo "agro-alimentar" mas é evidente, estão inseridos numa visão moderna da questão agrária. $^{121}$

Alberto Ballarín Marcial conclui asseverando que: "fundamos, pois, um direito agro-alimentar novo, com duas temáticas fundamentais. a agrária stricto sensu e o agro-alimentar", 122

Alberto Ballarín Marcial fala em agricultura "ecológica". conservadora e não destrutiva do solo e das águas e em agricultura "biológica" que conserva a genuidade dos alimentos confiando seu desenvolvimento na biologia, não ao estímulo químico de fertilizantes. Noticia que nos países desenvolvidos cresce a demanda para alimentos não contaminados, obtidos biologicamente. ${ }^{123}$

120. Consultar "Rivisıa di Dirilto Agrario", v. 63, III, 1984, p. 177-178, nota da redação da publicação. Em referida publicação encontram-se artigos dos autores que cuidaram do assunto.

121. Id. Ihidi. op. cit. p. 209, nota 5.

122. BALLARÍN MARCIAL, Alberto. "Dal Diritlo Agrário al Diritlo agro-alimentare", em Rnista di Dirillo Agrário. v. 63, 1984, p. 208-209.

123. Id. Ibid. op. cit. p. 220. 
Giovanni Cerretelli, Bruno Bagnoli e Marco Accordi informam que a expressão "agricultura ecológica" se desenvolve através de vários modelos, alguns criados na Europa na primeira metade do século XX. Tais modelos são conhecidos como "agricultura biodinâmica, agricultura biológica, agricultura regenerativa, agricultura orgânica, agricultura sustentável, agricultura alternativa, agricultura integrada, etc"

Asseveram que a medida que estes modelos de agricultura ecológica assumiram uma conotação mais precisa e econômica em vários paises, inclusive da C.E.E., reforçou-se a pressão em direção a uma regulamentação legislativa específica e orgânica para favorecer o desenvolvimento através de incentivos, disciplinando todas as diversas fases de produção e comercialização de modo a tutelar produtores e consumidores. $^{124}$

Em vários países há um aumento de áreas cultivadas de acordo com os critérios da agricultura biológica.

O desenvolvimento da agricultura biológica apenas ocorrerá com a realização de alguns objetivos prioritários: 1) características qualificativas elevadas dos produtos; 2) garantia da origem biológica: 3) continuidade nos fornecimentos: 4) diversificação suficiente das produções; 5) confeccionamento apropriado: 6) uso de marcas de qualidade e de origem; 7) educação do consumidor nas aquisições.

Os autores citados consideram a definição de agricultura biológica constante da lei do Texas como sulícientemente articulada e, pois, geralmente aceita: "Um sistema ecológico de gestão do solo em que seja garantida a manutenção de um alto porcentual de húmus através de rotações, acréscimo de fertilizantes orgânicos e uso somente quando necessário de meios de controle dos fatores adversos (instrumentos mecânicos, biológicos e químicos. caracterizados, de qualquer modo, por diminuto impacto ambiental)"

Alimento biológico define-se, ao invés, como: "Um produto obtido em empresas biológicas, feito, transformado e armazenado de modo tal a conservar o valor nutritivo no máximo e sem recurso algum a conservantes artificiais, corantes, aditivos, radiações ionizantes ou fitofármacos de síntese" 125

124. CERRETELLI, Giovanni. BAGNOLI, Bruno e ACCORDI, Marco Agricoltura biológica negli U.S.A., em Rivista di Diritlo Agrário. 1991. p. 24-26.

125. Id. Ibid. op. cit. p. 26. 
6. Análise da limitação à autonomia dos contratos agrários no Direito brasileiro.

O estudo interligado da função social da propriedade, do exercício da posse agrária e da função dos contratos agrários levou à redução das eventualidades em que ocorre a retomada da terra, principalmente, para explorá-la diretamente, passando para o arrendatário ou parceiro-outorgado grande parte do conteúdo do direito da propriedade.

Os contratos agrários foram submetidos a princípios da ordem social e econômica, com o que se procurou evitar descquilíbrios que se vinham configurando em sua execução. Na análise dos contratos agrários se impõe ter presente que o Direito Agrário coloca a terra, jurídica e economicamente, como um bem da produção.

Os contratos agrários são instrumentos jurídicos a surviço do cumprimento da função social da propriedade, as noções de função social da propriedade rural e função social dos contratos agrários se completam. Deste modo, configura-se a interligação e o caráter de complementariedade entre ambas as funções. ${ }^{126}$

O contrato agrário tem seu conteúdo examinado de modo especial. Numa perspectiva há o contrato agrário que organiza e disciplina o exercício de uma empresa agrária e há, também, o contrato agrário instrumento da empresa agrária já constituída e funcionando. Portanto, existem contratos agrários para a constituição da empresa agrária e os contratos de empresa agrária "stricto sensu" contratos agrários nominados (arrendamento e parceria), os contratos inominados, ou não regulados por normas legais (contrato agroindustrial), contratos que se formam sem contudo respeitar as regras gerais dos contratos nominados, o que revela exercício na autonomia contratual.

Já examinamos a restrição à liberdade contratual no contrato agrário disciplinado no contexto da C.E.E.

A legislação agrária brasileira prevê. em muitas matérias, a limitação à autonomia contratual.

126. HIRUNAKA, Giselda Maria Fernandes Novaes, A função social do contralo in "Fistudos Juridicos", v. 19, n. 47. setembro de 1986, p. 105-106. 
O art. 12 do Decreto n. 59.566/66 dispõe: “As partes poderão ajustar outras estipulações que julguem convenientes aos seus interesses, desde que não infrinjam o Estatuto da Terra, a Lei n. 4.947/66 e o presente Regulamento"

Paulo Torminn Borges enumera as limitações: "entre as vedações legais a de exigir o proprietário, do arrendatário ou do parceiro: I - prestação de serviço gratuito; II - exclusividade de venda da colheita; III - obrigatoriedade do beneficiamento da produção em seu estabelecimento; IV - obrigatoriedade da aquisição de gêneros e utilidades em seus armazéns ou barracões; V - aceitação de pagamento em 'ordens" 'vales' 'borós' ou outras formas regionais substitutivas da moeda" objeto do art. 93 do Estatuto da Terra, o que significa que esta disponibilidade legal não esgota a lista das vedações legais.

Com efeito, o art. 15 do Decreto n. 59.566/66 dispõe que: "A alienação do imóvel rural ou a instituição de ônus reais sobre ele não interrompe os contratos agrários, ficando o adquirente ou o beneficiário sub-rogado nos direitos e obrigações de alienante ou do instituidor do ônus (art. $92, \S 5^{\circ}$. do Estatuto da Terra"), outra regra importante limitante da liberdade de contratar.

A legislação brasileira prevê cláusulas que submetem os contratos agrários ao seu império, como ressalta Paulo Torminn Borges que as enumera" "a) obrigatoriedade de cláusulas que assegurem a conservação dos recursos naturais da terra (Lei n. 4.947/66, art. 13 III; Decreto n. 59.566/66, art. 13, II; b) obrigatoriedade de cláusulas que assegurem a proteção social e econômica do arrendatário ou do parceiro do parceiro - outorgado (Dec. n. 59.566, art. 13, VII; Lei n. 4.947, art. 13, $\mathrm{V})$; c) irrenunciabilidade dos direitos e vantagens legalmente definidos em prol do arrendatário ou parceiro - outorgado (Lei n. 4.947, art. 13, IV; Dec. n. 59.566, arts. $2^{\circ}$ e 13, l: d) proibição de usos e costumes predatórios da economia agrícola (Estatuto da Terra, art. 93; Lei n. 4.947, art. 13, I; Dec. n. 59.566, art. 13, VII, b)" 127

O saudoso e emérito jusagrarista Professor Fernando Pereira Sodero indica a existência de sete cláusulas obrigatórias, portanto, limitadoras da autonomia nos contratos agrários: I proibição de renúncia dos direitos ou vantagens estabclecidas em lei ou regulamento, por parte dos arrendatários e parceiros outorgados; II 'o observância das seguintes normas, visando a conservação dos recursos naturais: a) prazos mínimos, na forma da alinea " $b$ " no inciso XI, art. 95, e 
da alínea "b" do inciso V. do art. 96, do E.T. (Estes dispositivos da Lei n. 4.504/64 haviam determinado que, na regulamentação, seriam complementadas condições que, obrigatoriamente, constariam dos contratos agrários, dentre as quais as que cuidassem dos prazos mínimos de locação ou de duração e limites de vigência para os vários tipos de atividades agrícolas), que foram estabelecidos como os seguintes: - de 3 (três) anos. nos casos de arrendamento em que ocorra atividade de exploração de lavoura temporária e/ou de pecuária de pequeno e médio porte, ou $\mathrm{cm}$ todos os casos de parceria; de 5 (cinco) anos, nos casos de arrendamento em que ocorra atividade de exploração de lavoura permanente e/ou pecuária de grande porte para cria, recria, engorda ou extração de matérias-primas de origem animal; de 7 (sete) anos, nos casos em que ocorra atividade de exploração florestal: b) observância, quando couberem, das normas estabelecidas pela Lei n. 4.771, de 15-9-1965, Código "Florestal" e de seu Regulamento, constante do Decreto n. 58.016, de 18-3-1966"; c) observância de prática agrícolas admitidas para os vários tipos de exploração intensas e extrativa para as diversas zonas típicas do país, fixados nos Decretos n. 55.891. de 31-3-1965, e 56.792, de 26-8-1965; III - fixação, em quantia certa, do preço do arrendamento, a ser pago em dinheiro ou no seu equivalente em frutos ou produtos. na forma do art. 95 , inciso XII, do E.T. e do art. 17 do Regulamento, e das condições de partilha dos frutos, produtos ou lucros havidos na parceria conforme preceituam os arts. 96 do Estatuto e 39 do Regulamento: IV hases para as renovações convencionadas, seguindo o disposto no art. 95, incisos IV e V do Estatuto e o art. 22 do Regulamento; $\mathrm{V}$ - causas de extinção e rescisão, de acordo com o determinado nos arts. 26 e 34 do Regulamento; VI - direito e formas de indenização quanto às benfeitorias realizadas, ajustadas no contrato de arrendamento; e direitos e obrigações quanto às benfeitorias realizadas com consentimento do parceiro outorgante e quanto aos danos substanciais causados por práticas predatórias na área de exploração ou nas benfeitorias, instalações e equipamentos especiais, veículos, máquinas, implementos ou ferramentas cedidos ao parceiro - outorgado (art. 95. inciso XI, letra "c", e art. 96, inciso V, letra "e" do E.T.): VII - observância das seguintes normas. visando à proteção social e econômica dos arrendatárius e parceiros outurgados (art. 13, inciso V. da Lei n. 4.947/66) (.....): a) concordância do arrendador. ou do parceiro outorgante. à solicitação de crédito rural feita pelos arrendatários ou parceiros outorgados (art. 13, V, da Lei n. 4.497/66); b) cumprimento das proibições fixadas no art. 93 do Estatuto, a saber: prestação de serviço gratuito pelo arrendatário ou 
parceiro - outorgado; exclusividade da venda dos frutos ou produtos ao arrendador ou ao parceiro - outorgante; obrigatoriedade do beneficiamento da produção em estabelecimento determinado pelo arrendador ou pelo parceiro - outorgante; obrigatoriedade de aquisição de gêneros e utilidades em armazém ou barracões determinados pelo arrendador ou pelo parceiro - outorgante; aceitação pelo parceiro outorgado, de pagamento de sua parte em 'ordens' 'vales' 'borós ou qualquer outra forma regional substitutiva da moeda; direito e oportunidade de dispor dos frutos ou produtos repartidos da seguinte forma (art. 96, V, 'f', do E.T.): nenhuma das partes poderá dispor dos frutos ou produtos havidos antes de efetuada a partilha, devendo o parceiro - outorgado avisar o parceiro outorgante com a necessária antecedência, da data em que iniciará a colheita ou a repartição dos produtos pecuários; ao parceiro será garantido o direito de dispor livremente dos frutos e produtos que the cabem forçado contrato; em nenhum caso será dado em pagamento ao credor do cedente ou do parceiro outorgado, os produtos da parceria, antes de efetuada a partilha" 128

A matéria foi abordada, também. por Antonio Luiz Ribeiro Machado. ${ }^{129}$

Sobre a preservação dos recursos naturais da terra, foi preocupação dos jusagraristas desde a década dos anos 20 , e objeto da legislação renovadora a partir do Estatuto da Terra, com sua modemidade comprovada na Constituição Federal de 1988 como o apontou a Professora Giselda Maria Novaes Fernandes Hironaka, matéria que se insere, também, nas limitações à autonomia dos agrários. ${ }^{131}$

$\mathrm{O}$ art. 33 do Decreto n. 5.966 é também exemplo de limitação à liberdade de contratar, fundamentada a regra na preservação dos recursos naturais do solo e proteção social ao arrendatário.

São Paulo, dezembro de 2004.

128. SODI RO. Fernando Pereira, op. cit. p. II5.

129. MACHADO, Antonio Luiz Ribeiro, Manual prático dos contratos agrírios. 2. éd. rev. e atual. São Paulo: Revista dos Tribunais, 1979. p. 3-5; 17-19.

130. HIRONAKA, Giselda Maria Fernandes Novaes, Direito Agrário e os seus mecanismos para a conservação e a preservação do meio ambiente. Revista de Direito Civil, Imobiliário, Agrário e Limpresarial, ano 15, abril-junho de 1991. v. 56, p. 153-161. 


\section{ANEXO: ANOTAÇÕES SOBRE A ESPECIALIDADE DO DIREITO AGRÁRIO}

\section{CONCLUSÕES}

1 - O Direito Agrário se constitui por institutos que lhe dão a estrutura do sistema. Os seus institutos se compõem dos elementos preexistentes ao próprio sistema.

A individuação de eventuais princípios gerais passa, necessariamente, pelo trabalho prévio em torno dos diversos institutos formadores do Direito Agrário. O estudo comparativo dos mesmos pode levar ao surgimento de princípios gerais.

O Direito Agrário tem sua especialidade justificada pela existência de institutos próprios e não, como alguns admitiram, com a existência de princípios gerais.

O Direito Agrário é um ramo especial do Direito Privado, mais especificamente do Direito Civil, pelo exato problema da falta de determinação dos chamados princípios gerais. Tal fato não impede todavia, que se reconheça a validade e a importância da autonomia didática e científica do Direito Agrário.

Portanto, os princípios efetivamente próprios e pertinentes ao Direito Agrário não foram convenientemente formulados pelos que afirmam a existência dos mesmos.

Os princípios gerais podem surgir como elementos caracterizadores de um ou vários institutos de Direito Agrário, mas a especialidade comprova-se através dos institutos jurídicos. Até agora nenhum princípio geral de Direito Agrário foi formulado.

A especialidade do Direito Agrário se consubstancia através dos institutos jurídicos e não pelos princípios gerais.

Os supostos princípios gerais do Direito Agrário, até o momento apresentados, são ou demasiado amplos para serem. unicamente, peculiares ao Direito Agrário ou demasiado estreitos para que possam ser considerados comuns a totalidade de seus institutos.

2 Na base da especialidade do Direito Agrário encontra-se. sempre, a idéia da possibilidade teórica e da conveniência prática de separar a matéria fundiária, que corresponde ao Direito Civil, e a matéria agrária propriamente dita. 
A especialidade do Direito Agrário atenta para a particularidade de seu interior (parte interna do Direito) existir uma coordenação entre normas de Direito Privado e de Direito Público e, por conseqüência, seus institutos submetem-se a esta ampla influência.

A utilização do método de estudo por institutos pode, também, ajudar a determinar mais facilmente a existência da especialidade, assim como o grau alcançado por ela, constituindo um critério próprio da moderna escola de Direito Agrário.

O fato técnico constitui um dos fatores de especificação do direito agrário, idôneo a incidir sobre a especialidade da matéria com uma estruturação adequada dos preceitos. O fato técnico está presente em toda manifestação típica que transforma o direito agrário em um "jus proprium"

Para a constante adaptação do Direito Agrário a realidade. utiliza-se a técnica da complementação do dispositivo legal com referência ao fato técnico, com o que se realiza, indiretamente, a adequação do Direito à natureza do fato a regalar. Isto evidencia os motivos de natureza sócio-política das escolhas não apenas legislativas, mas interpretativas.

3 A existência da especialidade do Direito Agrário impõe, assim, o estudo da interpretação aplicada a este ramo do Direito.

A interpretação tende a ser evolutiva a esta noção que se expressa no campo do Direito Agrário e impõe, assim, o estudo da interpretação aplicada a este ramo do Direito.

A interpretação tende a ser evolutiva e esta noção se expressa no campo do Direito Agrário, ao se afirmar que, na agricultura, o direito nasce da natureza dos fatos e das coisas, ou seja, que as exigências de uma realidade em evolução criam problemas sempre novos que o agricultor deve ter presente c que o leva a adaptar seu comportamento. Como negar a juridicidade de seu comportamento se ele é secundum ius ou típico, desde que qualquer outro agricultor médio ter-se-ia conduzido do mesmo modo? O julgador deverá admitir a existência de normas não escritas, que as acolha sob o perfil de costume "praeter legem" quer sob o perfil de uma extensão ou restrição do significado das normas escritas.

Aplica-se ao Direito Agrário a "interpretação analógica" atravís da utilização de alguns de seus princípios gerais os quais auxiliam a explicação da 
"ratio" das normas agrárias. Com fundamento em tais princípios são claboradas as normas legais sobre Direito Agrário e agricultura. Entre os princípios devem ser indicados: principio do cultivo adequado, princípio da boa técnica agrária, noção de unidade produtiva, princípio da continuação da produção agrária.

A interpretação evolutiva se aplica ao Direito Agrário, quando o intérprete está preocupado com a objetividade das normas, isto é, tal como norma mostra-se evidente ao término de seu processo evolutivo no interior do ordenamento. É a norma que progride no contexto institucional, tendo em vista a própria modificação das relações, evolução esta que o intérprete não pode desprezar.

$\mathrm{Na}$ interpretação do Direito Agrário deve-se ter presente que este é, sobretudo, o direito que disciplina a empresa agrária, daí o ponto de referência da ratio para a interpretação das normas agrárias poder ser senão o ordenamento da empresa. Assim, o interesse da empresa, ou seja, a produção agrícola é a chave da interpretação do Direito Agrário.

A norma agrária, portanto, é sumpre instrumental com respeito aos tins da empresa agrária e, por conseqüência ser interpretada em função destes fins.

A ratio da norma agrária pode ser definida através de três critérios interpretativos: o princípio da normalidade dos acuntecimentos, da obrigatoriedade da conduta e o princípio da confiança. Os três critérios na interpretação do Direito Agrário são usados em função da empresa agrária e de seus fins produtivos.

O critério da normalidade pode ser exemplificada com a noção de exercício normal da agricultura, o intérprete deve-se referir a um critério objetivo. qual seja o que o agricultor normalmente faz para responder aos princípios da boa produção conforme a evolução da técnica agrícola e da ciência econômica.

O princípio da obrigatoriedade da conduta exigirá a pesquisa do critério da diligência do bom pai de família na avaliação do comportamento de quem administra ou tem a responsabilidade da direção da empresa. Por exemplo, o concessionário no uso da propriedade agrária. que é obrigado a atuar de conformidade com sua destinação agrária, segundo a diligência do bom pai de familia, fornecendo a serviço do empreendimento os instrumentos para sua gustão e observando as regras técnicas de boa empreitada.

O princípio da confiança também aparece no campo do Direito Agrário quando se tratar de problema interpretativo em matéria de contratos agrários, os quais são constitutivos da empresa agrária. 
A legislação brasileira indiretamente tem normas que interessam a interpretação de regra agrária: arts. $92, \S 9,96$, inciso VII e parágrafo único e 103 do Estatuto da Terra, art. 13 da Lei n. 4.947/66 e art. 88 do Decreto n. 59.566/66.

4 A legislação agrária deve conter o conceito econômico de agricultura, porque na prática tal omissão gera problemas; o intérprete da Lei tem de receber da norma uma direção clara, dedutivel da compreensão completa da relação por regular. O conceito de agricultura é, por sua natureza, científico-técnico e pré-jurídico.

Assim, a expressão "Direito da Agricultura" é uma fórmula superficialmente descritiva e de conteúdo ambíguo.

Existe a noção de agricultura - produção e agricultura proteção. A primeira significando a produção de bens através de estruturas produtivas ou por produtores individuais ou associativos. A segunda compreendendo a defesa dos cursos naturais. Está última adentra no objeto e na finalidade do Direito Agrário, porém apenas indireta e ocasionalmente, sempre em função do processo produtivo.

Por outro lado, a expressão Direito Agroalimentário, como substituta de Direito Agrário convencional, não se sustenta frente à objeção de que nem todos os produtos agrícolas são destinados à alimentação: pense-se no cultivo de fïbras têxteis ou de tabaco, e na própria floricultura.

O critério da agrariedade se consubstancia "na atividade produtiva agrícola consistente no desenvolvimento de um ciclo biológico, vegetal ou animal, ligada direta ou indiretamente ao desfrute das forças e dos recursos naturais e que resolve economicamente na obtenção de frutos, vegetais ou animais, destinados ao consumo direto, tais como são, submetidos a uma ou múltiplas; transformações" na lição abalizada de Antonio Carroza.

A atividade principal se orienta para a produção de animais e vegetais e por isso se denomina critério biológico, sendo o Direito Agrário o encarregado de regular todo o conjunto normativo relativo a este tipo de produção. Há uma certa identidade entre o objeto do Direito Agrário e a própria agrariedade, ou melhor, entre este e a agrariedade, junto com as atividades conexas, na lição fundamental de Ricardo Zeledón Zeledón.

Ruralidade ¿ agrariedade foram também examinadas com a contribuição do especialista Raymundo Laranjeira 
Examinou-se o critério agrobiológjco, que se constitui numa noção extrajurídica do fenômeno denominada teoria agrobiológica pela qual, na lição de Antonio Carroza: "a atividade produtiva agricola consiste no desenvolvimento de um ciclo biológico concernente à criação de animais ou vegetais, que surge ligado, diretu ou indiretamente, a função das forças e dos recursos naturais e que se explica economicamente na obtenção de frutos"

Acenou-se a noção de "cultura especializada"

O critério agrobiológico é qualificado como extrajurídico por não manter correspondência nos dados normativos.

O ciclo biológico de produção é o processo orgânico realizado pelo agricultor e necessário para a obtenção dos bens desejados. O ciclo biológico pode, contudo, coincidir ou-não com o ciclo produtivo.

A presença do fundo não pode ser considerada fundamental! na qualificação do exercício da agricultura, como foi examinado. Basta asseverar que o cultivo "sem-terra" para certos vegetais é o único possível tecnicamente e o único conveniente economicamente.

O conceito de boa técnica agrária se modernizou por causa do progresso científico e tecnológico, que permitiu colocar a natureza em condições sempre mais prováveis para a produção. Surgem os cultivos protegidos, que ocorrem em estufas e por outros mecanismos.

Ao lado da atividade agrícola há a atividade zootécnica que ao se especializar criou, o Direito Zootécnico. Esta atividade zootécnica se desenvolve em terra e sem-terra. Novas formas contratuais surgiram neste contexto. Fala-se da necessidade de regulamentação da atuação da empresa zootécnica; sustenta-se a oportunidade para que esta tenha seu estatuto.

Igualmente, a integração da agricultura origina os processos de integração horizontal e vertical como resultado de acordos entre grupos de empresários para o exercício de urna atividade. É o campo de atuação dos contratos agroindustriais e dos acordos interprofissionais.

Apontou-se a vantagem obtida através das várias formas de integração na agricultura.

5 A atividade agrária revela particularidades no desenvolvimento do ciclo produtivo. Impõe-se a análise da função e posição que devem ser reconhecidas aos sujeitos de 
direito que participam de atividades, como também do estudo da função e disciplina do objeto de tal atividade (o solo produtivo), as quais devem ser consideradas seja no ponto de vista estritamente econômico da produção, seja do ponto de vista políticosocial e, também, no jurídico. Por fím deve-se atentar para a organização dos meios necessários para desenvolver proficuamente tais atividades.

Analisou-se o conceito de agricultor sob o seu elemento subjetivo e ai a importância da profissionalidade.

O elemento subjetivo se configura, também, quando o agricultor se investe no uso agrícola do solo, quando se associa com seu trabalho.

É também sujeito de atividade agrária quem participa da comunhão tácita familiar ou da denominada propriedade familiar. O núcleo familiar atua como organismo unitário produtivo.

O elemento associativo é, com efeito, muito importante na organização da agricultura, através das cooperativas agrárias.

6 - O conceito de agricultura, analisado sob vários ângulos, tem a perspectiva objetiva desenvolvida através da classificação da atividade agrária, da indicação dos diversos tipos de atividades próprias da agricultura.

Na elaboração da classificação das atividades agrárias deverão estar presentes dois conceitos: de natureza e organização, considerados a partir de seus significados específicos.

Num primeiro modelo de classificação das atividades agrárias, há três espécies fundamentais de atividades nas formas mais elementares da agricultura, dirigidas a produção, a transformação e a troca.

No estudo da classificação das atividades agrárias os jusagraristas utilizam três critérios: da normalidade, da acessoriedade e da prevalência.

Neste sentido, a classificação das atividades agrárias formuladas por jusagraristas nacionais foi examinada.

Ao final, verificou-se que a classificação das atividados agrárias, tal como demonstram os exemplos e as referendas desenvolvidas, estabelece-se a partir de uma enumeração exemplificava e não taxativa.

7 - A disciplina da empresa agrária é pobre de normas particulares. As obrigações recaem sobre o empresário e não sobre o proprietário da terra. A empresa agrária se 
distinguiria das pessoas jurídicas denominadas civis tão-somente pelo objeto e não pela estrutura.

O empresário agrário apresenta-se isolado das atividades mercantis.

A empresa agrária é, de fato, o instituto central do Direito Agrário.

As obrigações do empresário agrário, as empresas coletivas agrárias e seus tipos, as associações de empresas agrárias, o pequeno empresário agrário foram alguns dos temas abordados.

A ligação empresa-contrato agrário é profunda e o contrato agrário pode se constituir no embrião do estabelecimento.

Fxaminou-se o novel instituto da unidade produtiva, que se caracteriza pelas condições objetivas de rentabilidade ou produtividade que permitam a formação de uma empresa agrária válida sob o perfil técnico e econômico.

A unidade produtiva é um ponto de referência que concerne à renda do trabalho na agricultura, sempre comparável com a renda do trabalho em alguns setores produtivos. A unidade produtiva se revela. sem dúvida, adequada aos objetivos de urna agricultura moderna.

Podemos adaptar a noção de unidade produtiva ao Direito brasileiro, entendendo-a como tendo por objeto os contratos agrários como regulados na legislação especial.

Referido instituto eqüivale. no Direito brasileiro ao instituto do módulo rural ou aos índices GUT para avaliar o grau de produtividade da terra. como previsto no Estatuto da Terra ou nas decisões normativas dos órgãos federais competentes.

Os institutos da unidade produtiva, mínima unidade cultura!, módulo rural e propriedade familiar exigem uma nova concepção das dimensões do estabelecimento agrário, por causa da mecanização e especialização das culturas.

$O$ instituto da unidade produtiva desloca a importância da função social da terra para a função social da empresa agrária. com a amplidão e ausência de formalidades objetivas na regulação desta última.

A empresa agrária foi analisada no Direito brasileiro, tendo-se apontado que a propriedade familiar pode ser admitida como um tipo de empresa agrária.

A perspectiva do reconhecimento da atividade do empresário rural no Projeto de Código Civil foi também analisada. 
Concluiu-se que a regulamentação superficial da empresa agrária seguiu o modelo italiano, procurando-se afastar a confirmação da comercialidade e deixando que a legislação especial ordene as normas.

8 Após examinar o instituto empresa agrária, a sćqüência lógica foi apontar a especialidade do estabelecimento agrário, matéria pouco abordada mas relevante.

Os elementos do estabelecimento agrário variam igualmente, como ocorre com a noção de agraricdade da empresa.

Por outro lado a atividade agrária não é essencialmente urna atividade de troca o que impede a aplicação integral da disciplina do estabelecimento agrário.

$O$ estabelecimento agrário pode ser, outrossim, objeto dos contratos agrários.

O elemento fundo foi sopesado, para se concluir que nem sempre é primordial. Exemplo do asseverado está na empresa zootécnica.

O estabelecimento agrário se compõe de elementos fíxos e de elementos circulantes.

A razão social, marca, o fundo de comércio têm, no estabelecimento agrário, importância reduzida se comparados com seu relevo no estabelecimento comercial. Mas o fundo de comércio adquire características importantes na disciplina do estabelecimento agrário.

O instituto desvio de clientes, por causa de sua organização de venda, não subsiste no estabelecimento agrário. O uso de marcas, contudo, cada vez mais se apresenta como elemento beneficiador do estabelecimento agrícola.

O art. 25 do Decreto n. 55.891 contunde a noção de empresa rural. aproximando a acepção de empresa da noção de estabelecimento agrário.

O contrato agrário i igualmente um instituto relevantíssimo na configuração da especialidade do Direito Agrário.

Neste sentido, autores modernos tèm construido a teoria do contrato agrário exclusivamente com referência a empresa, abandonado o fundo como objeto do negócio jurídico agrário.

Há dissídio na qualificação do contrato de trabalho e de contrato de crédito agrário como integrantes da categoria em exame. 
A limitação da autonomia da vontade na formação dos contratos agrários e as conseqüências quanto à sua tipologia foram estudadas a nível doutrinário e na legislação brasileira.

Além disso o instituto da conversão dos contratos agrários não poderia deixar de constar do capítulo, vez que tem sido inserido na legislação reformadora de muitos países por decisão de diretiva da C.E.E.

A convertibilidade dos contratos associativos mereceu assim atenção dentro da análise geral do novo instituto.

O contrato agroindustrial foi também enfocado como contrato típico de exercício da empresa agraria, contrato associativo que é.

A possibilidade da absorção do Direito Agrário convencional pelo denominado Direito agroalimentar por outro lado foi afastada.

Acenou-se para o impacto da agricultura biológica obrigando a um alargamento do Direito Contratual Agrário.

Portanto, o desenvolvimento do trabalho objetivou apontar os aspectos mais relevantes sobre a especialidade do Direito Agrário e para tanto foi necessário abordar temas gerais desta área, analisar temas fundamentais da implicação jurídica da agricultura, para em seguida apontar lineamentos mais significativos da especialidade em três institutos dos seus. 